\title{
А.Л. Синица
}

\section{ЧИСЛО ДОМОХОЗЯЙСТВ С ДЕТЬМИ РАЗЛИЧНОГО ТИПА ПО ДАННЫМ ПЕРЕПИСЕЙ НАСЕЛЕНИЯ 2002 и 2010 гГ.}

\begin{abstract}
На основе данных переписей населения 2002 и 2010 г2. в статье рассматривается изменение числа домохозяйств с одним, двумя, тремя и более детьми до 18 лет в регионах России. Анализ показал, что ситуаџия была лучше в регионах с высоким уровнем жизни и в регионах с высокой рождаемостью, а более плохой - в северных регионах $и$ в центральной части России. В качестве причин, обусловливающих различия, выделяются культурные и экономические особенности, а также демографическое развитие в 1980-1990-е г2.

Ключевые слова: домохозяйство, дети, регионы, Россия, конвергенция, дифференциаичия, демографическое развитие, перепись населения, сочиальная политика, семья.
\end{abstract}

\section{Введение}

В преддверии публикации результатов микропереписи населения, проведенной в 2015 г., стоит рассмотреть данные переписей населения 2002 и 2010 гг., которые, к сожалению, до сих пор по ряду вопросов слабо введены в научный оборот. Это необходимо как для исследователей, так и для органов власти, поскольку переписи дают точные и достоверные сведения о демографическом развитии и последствиях принимаемых ими решений.

В значительной мере это касается рождаемости, так как в настоящее время только перепись населения позволяет получить данные в масштабе всей страны о числе детей разной очередности рождения (Федеральный закон от 15.11.1997 г. № 143-Ф3 «Об актах гражданского состояния» исключил такие сведения из перечня собираемых, что, безусловно, значительно ухудшило управляемость страной).

Однако переписи населения также являются практически единственным источником данных о числе семей и домохозяйств, их среднем размере и многих других важных аспектах брачно-семейных отношений.

Почему важно знать число домохозяйств в стране?

Во-первых, из-за неразвитости социальной инфраструктуры в регионах РФ многие виды деятельности осуществляются дома. Для развития, отвечающего интересам жителей, необходимо знать число первичных ячеек общества и прогнозировать динамику изменения их численности.

Во-вторых, многие сферы общественной жизни зависят не только от числа домохозяйств в целом, но и от их структуры (числа домохозяйств различных видов). Например, воспитывать ребенка в домохозяйстве, состоящем из

\footnotetext{
${ }^{1}$ Публикация подготовлена в рамках гранта РФФИ «Причины и последствия дифференциации демографического развития регионов России и возможности ее сокращения» (№ 15-06-09027).
} 
родителя с ребенком или из родителя с ребенком и родственником, а также в разведенной семье, гораздо сложнее по сравнению с домохозяйством, в котором есть оба родителя, а социализация детей из домохозяйств первого типа затруднена [1-3]. Различные социальные институты могут смягчить последствия воспитания в неполных семьях, но для этого им необходимо знать число таких семей и прогнозировать динамику изменения их числа.

В-третьих, среднее число детей и других членов в домохозяйствах в регионах различается, поэтому уровень спроса на различные социальные услуги и его структура тоже различаются. Следовательно, региональная политика должна быть комплексной (включать в себя все аспекты и увязывать социальные и демографические показатели), но акцент в них должен делаться именно на региональных, достичь чего, не имея сведений о числе семей и домохозяйств, нельзя.

В-четвертых, известно, что у родителей, которые росли в семье с большим числом детей, детей в среднем больше по сравнению с родителями из малодетных семей. Они знают специфику жизни таких семей и более подготовлены к ее созданию. В связи с этим необходимы меры, направленные на повышение привлекательности таких семей, разработать которые, не зная изменения их числа, нельзя.

В-пятых, демографические процессы имеют большую инерцию, поэтому для изменения текущей ситуации необходимы знания о предшествующих изменениях за большой промежуток времени. Давать оценку результативности проводимой политики и разрабатывать прогнозы без знания числа домохозяйств разных типов тоже нельзя, поскольку при разной структуре домохозяйств и населения в целом необходимы разные меры.

В-шестых, число домохозяйств и их структура зависят от многих социальных, экономических, демографических и прочих факторов. В связи с этим данные показатели можно рассматривать как некий синтетический показатель уровня развития страны в целом или ее отдельного региона.

\section{Предмет и метод исследования}

Несмотря на то, что изменение числа домохозяйств с разным числом детей в России и ее регионах является важным вопросом, значительно влияющим на ее социально-экономическое развитие, в настоящее время он рассмотрен недостаточно полно.

В современных работах исследован уровень жизни неполных семей [4], домохозяйства с тремя и более детьми [5-6], число семей и домохозяйств в отдельных регионах (в том числе в сельской местности) [7-8], изменение структуры домохозяйств [9-10], а также факторы, влияющие на изменение их размеров [11], последствия изменений, происходящих в институте семьи [12], характеристики домохозяйств по данным только переписи 2002 [13-14] или 2010 [15] г., но обойдено вниманием изучение изменения числа домохозяйств с разным числом детей, что обусловливает актуальность данной темы.

Целью нашего исследования является изучение числа домохозяйств с одним, двумя, тремя и более детьми до 18 лет (далее - домохозяйства с детьми), числа их членов, их среднего размера, доли таких домохозяйств среди всех 
домохозяйств и среди всех домохозяйств с детьми в 2002 и 2010 гг. Указание возраста является важным дополнением, так как следует различать домохозяйства, в которых проживают родители с детьми, и домохозяйства, в которых проживают родители с детьми до 18 лет, так как к первому типу домохозяйств относятся те, в которых дети могут быть гораздо старше 18 лет.

Источниками информации являются материалы всероссийских переписей населения 2002 и 2010 гг. Микроперепись 1994 г. была исключена из рассмотрения в силу отсутствия в ней данных о числе домохозяйств с детьми.

Между 2002 и 2010 гг. число и состав федеральных округов значительно изменились, поэтому сравнительный анализ федеральных округов не проводится.

В связи с наличием только двух точек (2002 и 2010 гг.) мы не можем рассмотреть б-конвергенцию, поэтому для изучения того, с какой скоростью и в каком направлении происходит движение домохозяйств к устойчивому состоянию, мы будем использовать абсолютную $\beta$-конвергенцию [16], наличие которой является необходимым, но не достаточным условием существования $\sigma$-конвергенции.

Регрессия Барро ( $\beta$-конвергенция) представляет собой следующее уравнение:

$$
\ln \left(\frac{\text { Показатель }}{\text { Показатель }}\right) / T=\alpha+\beta \ln (\text { Показатель })+\varepsilon
$$

где Показатель ${ }_{T}$ - значение показателя на момент времени $T$; Показатель 0 значение показателя на начальный момент времени; $T$ - рассматриваемый временной период; $\alpha$ - константа; $\beta$ - коэффициент конвергенции (в данной форме уравнения тестируется гипотеза о том, что $\beta<0$ ); $\varepsilon$ - стандартная ошибка.

\section{Изменение числа домохозяйств с детьми до 18 лет с одним ребенком}

За межпереписной период число домохозяйств с одним ребенком сократилось с 13829 тыс. до 11705 тыс. (на 15,4\%), а число членов в них - с 46411 тыс. чел. до 39567 тыс. чел. (на 14,7\%). В результате средний размер таких домохозяйств немного возрос - с 3,36 чел. до 3,38 (на 0,7\%).

Несмотря на значительное снижение числа домохозяйств с одним ребенком в республиках Дагестан, Ингушетия, Чеченская, Тыва, их число возросло (соответственно на 33,$4 ; 29,4 ; 43,0 ; 1,0 \%$ ). Снижение в размере менее $10 \%$ было отмечено в шести регионах: республиках Кабардино-Балкарская (на $3,9 \%$ ), Карачаево-Черкесская (на 2,3\%), Северная Осетия (на 7,6\%), Саха (Якутия) (на 5,5\%), Ставропольском крае (на 9,6\%), г. Москве (на 3,0\%). Наибольшее снижение отмечалось в Магаданской (на 30,5\%), Мурманской (на 26,4\%), Псковской (на 25,0\%), Курганской (на 24,8\%), Сахалинской (на $24,2 \%$ ), Тамбовской (на 23,7\%), Тульской (на 23,3\%), Кировской (на 23,1\%) областях и Республике Карелия (на 23,6\%). 
Снижение числа домохозяйств с одним ребенком отмечалось преимущественно в северных регионах и регионах центральной полосы: Центральном (ЦФО), Северо-Западном (СЗФО), Дальневосточном федеральных округах (ДФО). Это связано как с миграционным оттоком, так и с увеличением доли домохозяйств с другим числом детей. Небольшое снижение или рост числа таких домохозяйств наблюдались в регионах с высокой рождаемостью и в Москве, что можно объяснить снижением в первых числа домохозяйств с тремя и более детьми и высоким уровнем жизни и миграционным притоком.

Доля домохозяйств с одним ребенком среди всех домохозяйств сократилась с 33,8 до 28,9\%, т.е. на 14,5\%. Максимальной (36\% и более в 2002 г.) доля таких домохозяйств была в Калининградской, Тюменской, Сахалинской, Магаданской, Мурманской областях, Республике Коми, Хабаровском, Камчатском краях, Чукотском автономном округе. Наиболее низкой (менее $27 \%$ в 2010 г.) их доля была в республиках Ингушетия, Чеченская, Северная Осетия, Дагестан, Кабардино-Балкарская, Карачаево-Черкесская, Адыгея, г. Москве $(26,5 \%)$.

Наиболее значительным сокращение было в Магаданской (на 18,7\%), Мурманской (на 18,6\%), Калужской (на 18,3\%), Рязанской (на 17,6\%), Калининградской (на 17,2\%), Владимирской (на 17,2\%), Пензенской (на 17,1\%) областях и в г. Санкт-Петербург (на 19,3\%). Наименьшим снижение было в республиках Калмыкия (10,0\%), Карачаево-Черкесская (8,4\%), Северная Осетия (8,2\%), Саха (Якутия) (7,4\%), Тыва (1,7\%), Кабардино-Балкарская $(1,3 \%)$, Забайкальском крае $(9,0 \%)$, а в республиках Дагестан, Чеченская, Ингушетия их доля увеличилась на 10,$7 ; 12,6$ и 22,8\%. В трех последних регионах доля таких домохозяйств была самой низкой, поэтому ее увеличение связано с замедлением прироста рождаемости в этих регионах.

Снижение было наибольшим в ЦФО и СЗФО (в регионах с самой низкой рождаемостью, в которой она восстанавливалась после событий 1990-х гг.), а небольшое снижение или увеличение доли таких домохозяйств - в регионах с высокой рождаемостью, в которых в основном прирост рождаемости замедляется: Южном (ЮФО) и Северо-Кавказском (СКФО) федеральных округах.

Доля домохозяйств с одним ребенком среди всех домохозяйств с детьми в среднем по стране составляет 65\%. Наиболее высокой (более 72\% в 2002 или 2010 г.) их доля была в Магаданской, Московской, Владимирской, Мурманской, Ивановской, Ярославской, Смоленской, Тульской областях, городах Москве и Санкт-Петербурге (в нем около 75\%). Наиболее низкой (50\% и менее) их доля была в Республиках Калмыкия, Карачаево-Черкесская, Северная Осетия, Кабардино-Балкарская, Тыва, Дагестан, Чеченская, Ингушетия (в двух последних доля составляла всего 15-25\%).

Снижение доли таких домохозяйств было отмечено в 29 регионах. Более чем на 1,5\% она снизилась в Московской (на 3,0\%), Магаданской (на 2,8\%), Калининградской (на 2,1\%), Сахалинской (на 1,8\%), Мурманской (на 1,8\%) областях, республиках Алтай (на 3,5\%), Адыгея (на 1,7\%), в Чукотском автономном округе (на $3,1 \%$ ), г. Москве (на 2,6\%). Прирост в размере более $5 \%$ был отмечен в Ульяновской области $(5,4 \%)$, республиках Башкортостан $(5,5 \%)$, Марий Эл (5,7\%), Калмыкия (6,1\%), Татарстан $(6,7 \%)$, Чувашская 
(7,2\%), Кабардино-Балкарская (11,7\%), Чеченская (22,1\%), Дагестан $(23,0 \%)$, Ингушетия (42,0\%).

Снижение наблюдалось практически во всех федеральных округах, что связано с реализацией отложенных рождений, а увеличение - в ЮФО, СКФО и Приволжском федеральном округе (ПФО). В ЮФО и СКФО причиной является замедление темпов роста рождаемости, а в ПФО причина не ясна и требует дополнительного изучения.

Несмотря на снижение числа членов домохозяйств в целом по стране, в ряде регионов оно выросло: в республиках Дагестан (на $32,7 \%$ ), Ингушетия (на 12,3\%), Карачаево-Черкесская (на 3,2\%), Чеченская (на $32,4 \%$ ), Тыва (на $1,7 \%$ ). В восьми регионах снижение составило менее $10 \%$ : в Московской области (9,9\%), республиках Кабардино-Балкарская (2,2\%), Калмыкия (6,6\%), Северная Осетия (4,3\%), Татарстан (8,8\%), Саха (Якутия) (4,3\%), Ставропольском крае $(7,0 \%)$, г. Москве $(2,8 \%)$. Снижение было максимальным в Рязанской $(22,3 \%)$, Владимирской $(22,4 \%)$, Тамбовской $(22,5 \%)$, Тульской $(23,4 \%)$, Кировской $(23,7 \%)$, Сахалинской $(23,7 \%)$, Курганской $(24,8 \%)$, Псковской $(24,8 \%)$, Мурманской $(27,7 \%)$, Магаданской $(30,5 \%)$ областях, республиках Коми (23,6\%), Карелия (23,9\%), Камчатском крае $(23,0 \%)$.

Число членов снижалось в ЦФО, СЗФО и ДФО из-за увеличения рождаемости, что привело к увеличению числа детей более высоких очередностей рождения и миграционного оттока в ряде регионов. В регионах с высокой рождаемостью снижение числа членов связано с нуклеаризацией общества и увеличением числа домохозяйств с одним ребенком.

Несмотря на то, что средний размер домохозяйства с одним ребенком в РФ увеличился, в 28 регионах он сократился. В 25 из них сокращение составило менее $1 \%$, но в трех оно было больше: в Мурманской области $-1,8 \%$, в Чеченской Республике - 7,4\%, в Республике Ингушетия - 13,2\%. В восьми регионах средний размер увеличился более чем на $2 \%$ : в Астраханской области (на 2,7\%), республиках Мордовия (на 2,1\%), Бурятия (на 2,3\%), Марий Эл (на 2,5\%), Адыгея (на 2,6\%), Северная Осетия (на 3,6\%), КарачаевоЧеркесская (на 5,7\%), Калмыкия (на 6,4\%).

Увеличение среднего размера домохозяйств можно связать с тем, что многочисленные поколения, рожденные в 1980-е гг., становились старше 18 лет, но продолжали жить с родителями, снижение - с различными тенденциями, связанными с нуклеаризацией общества в таких регионах.

Сближались ли регионы по числу домохозяйств с одним ребенком, числу членов в них и их размеру в межпереписной период или различия увеличивались?

В табл. 1 представлены результаты эконометрического моделирования. В модели 1 изучается сближение по числу домохозяйств с одним ребенком, в модели 2 - по доле домохозяйств с одним ребенком среди всех домохозяйств, в модели 3 - по доле домохозяйств с одним ребенком во всех домохозяйствах с детьми, в модели 4 - по числу членов домохозяйств с одним ребенком, в модели 5 - по среднему размеру домохозяйств с одним ребенком. 
Таблица 1

Модели конвергенции характеристик домохозяйств с одним ребенком

\begin{tabular}{|c|c|c|c|c|c|}
\hline Модель 1 & Коэффициент & $\begin{array}{c}\text { Стандартная } \\
\text { ошибка } \\
\end{array}$ & $\begin{array}{l}\text { Р-зна- } \\
\text { чение }\end{array}$ & $\begin{array}{l}\text { R-ква- } \\
\text { драт }\end{array}$ & 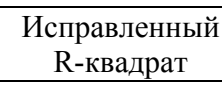 \\
\hline const & 0,01230 & 0,01767 & 0,4883 & \multirow[t]{2}{*}{0,0393} & \multirow[t]{2}{*}{0,0270} \\
\hline 1_v2002 & $-0,00269$ & 0,00151 & 0,0781 & & \\
\hline$\overline{\text { Модель } 2}$ & Коэффициент & $\begin{array}{l}\text { Стандартная } \\
\text { ошибка }\end{array}$ & Р-значение & $\begin{array}{l}\text { R-ква- } \\
\text { драт }\end{array}$ & $\begin{array}{l}\text { Исправленный } \\
\mathrm{R} \text {-квадрат }\end{array}$ \\
\hline const & 0,13010 & 0,00867 & $7,15 \mathrm{e}-025$ & \multirow[t]{2}{*}{0,7858} & \multirow[t]{2}{*}{0,7831} \\
\hline 1_v2002 & $-0,04184$ & 0,00247 & $8,05 \mathrm{e}-028$ & & \\
\hline Модель 3 & Коэффициент & $\begin{array}{l}\text { Стандартная } \\
\text { ошибка }\end{array}$ & Р-значение & $\begin{array}{l}\text { R-ква- } \\
\text { драт }\end{array}$ & $\begin{array}{l}\text { Исправленный } \\
\mathrm{R} \text {-квадрат }\end{array}$ \\
\hline const & 0,09020 & 0,00509 & $4,49 \mathrm{e}-029$ & \multirow[t]{2}{*}{0,7940} & \multirow[t]{2}{*}{0,7913} \\
\hline l v2002 & $-0,02134$ & 0,00123 & $1,77 \mathrm{e}-028$ & & \\
\hline Модель 4 & Коэффициент & $\begin{array}{l}\text { Стандартная } \\
\text { ошибка }\end{array}$ & Р-значение & $\begin{array}{l}\text { R-ква- } \\
\text { драт }\end{array}$ & $\begin{array}{l}\text { Исправленный } \\
\mathrm{R} \text {-квадрат }\end{array}$ \\
\hline const & 0,00085 & 0,01890 & 0,9644 & \multirow[t]{2}{*}{0,0137} & \multirow[t]{2}{*}{0,0010} \\
\hline 1_v2002 & $-0,00152$ & 0,00146 & 0,3019 & & \\
\hline Модель 5 & Коэффициент & $\begin{array}{l}\text { Стандартная } \\
\text { ошибка }\end{array}$ & Р-значение & $\begin{array}{l}\text { R-ква- } \\
\text { драт }\end{array}$ & $\begin{array}{l}\text { Исправленный } \\
\mathrm{R} \text {-квадрат }\end{array}$ \\
\hline const & 0,01951 & 0,00352 & $4,04 \mathrm{e}-07$ & \multirow[t]{2}{*}{0,2746} & \multirow[t]{2}{*}{0,2653} \\
\hline 1_v2002 & $-0,01573$ & 0,00289 & $6,10 \mathrm{e}-07$ & & \\
\hline
\end{tabular}

Источник: расчеты автора на основе [17-18].

Несмотря на сближение регионов по числу домохозяйств с одним ребенком и числу членов в них, R-квадрат в моделях 1 и 4 крайне низкий, а значимость недостаточная, поэтому мы не можем использовать их в работе. Модель 5 значима на уроне 1\%, хотя R-квадрат в ней небольшой, поэтому мы можем предполагать сближение регионов по среднему размеру домохозяйств, но должны не упускать из вида, что существуют важные неучтенные в ней факторы. В моделях 2 и 3 R-квадрат высокий, и они значимы на уровне $1 \%$. При этом наблюдается сближение регионов по доле домохозяйств. Сближение регионов во всех моделях (движение в сторону некоторого устойчивого равновесия) можно объяснить снижением числа домохозяйств и домохозяйств с детьми, реализацией отложенных рождений и замедлением темпов прироста рождаемости в регионах Северного Кавказа.

\section{Изменение числа домохозяйств с детьми до 18 лет с двумя детьми}

За межпереписной период число домохозяйств с двумя детьми сократилось с 5971 тыс. до 4922 тыс. (на 17,6\%), число членов них - с 25802 тыс. чел. до 21543 тыс. (на 16,5\%), а средний размер домохозяйства с двумя детьми увеличился с 4,32 чел. до 4,38 (на 1,3\%).

Несмотря на снижение числа домохозяйств с двумя детьми в целом по стране, в республиках Дагестан, Ингушетия, Чеченская и г. Москве оно возросло на 9,$0 ; 13,1 ; 16,9$ и $1,3 \%$ соответственно. Снижение в размере $25 \%$ и более было отмечено в 17 регионах: Оренбургской (на 25,3\%), Пензенской (на 25,3\%), Омской (на 25,4\%), Орловской (на 25,5\%), Смоленской (на $25,9 \%$ ), Брянской (на 26,4\%), Псковской (на 26,5\%), Курской (на 27,7\%), Кур- 
ганской (на 27,8\%), Тамбовской (на 27,9\%), Кировской (на 27,9\%), Ульяновской (на 34,8\%) областях, республиках Карелия (на 25,2\%), Коми (на 25,5\%), Чувашская (на 27,8\%), Марий Эл (на 28,7\%), Мордовия (на 31,4\%). Мы видим, что рост или наименьшее снижение таких домохозяйств было в регионах с высокой рождаемостью или с высоким уровнем жизни (в прочих регионах ЮФО и СКФО, Тюменской области, Республике Саха (Якутия) снижение составило 10-12\%). Наибольшим снижение было в основном в регионах ЦФО и ПФО, т.е. в регионах, в которых рождаемость не восстановилась по сравнению с 1980-ми гг.

Доля домохозяйств с двумя детьми среди всех домохозяйств сократилась с 14,6 до $12,1 \%$, т.е. на 17,1\%, Наиболее высокой (20\% и более в 2002 г.) она была в Республиках Бурятия, Саха (Якутия), Алтай, Северная Осетия, Карачаево-Черкесская, Чеченская, Кабардино-Балкарская, Калмыкия, Тыва, Дагестан. Наиболее низкой (10\% и менее в 2010 г.) доля была в Тульской, Ярославской, Ивановской, Рязанской, Смоленской, Псковской, Ленинградской, Воронежской областях, городах Москве и Санкт-Петербурге.

Доля домохозяйств с двумя детьми среди всех домохозяйств увеличилась только в Республике Ингушетия (на 7,2\%). Еще в шести регионах убыль составила менее 10\%: в Московской области (9,5\%), республиках Дагестан $(9,5 \%)$, Чеченская $(8,0 \%)$, Алтай $(7,0 \%)$, Тыва $(7,0)$, Чукотском автономном округе (6,2\%). Наибольшим снижение было в Омской (на 22,6\%), Белгородской (на 23,2\%), Ульяновской (на 30,9\%) областях, республиках Башкортостан (на 24,3\%), Чувашской $(24,9 \%)$, Татарстан (на 25,1\%), Марий Эл (на $25,2 \%)$, Мордовия (на 27,1\%).

Снижение доли было наименьшим в Сибирском федеральном округе (СФО) и СКФО, так как в них рождаемость выше, а наибольшим - в ПФО, поскольку рождаемость в нем не восстановилась.

Доля домохозяйств с двумя детьми среди всех домохозяйств с детьми сократилась с 28,2 до 27,5\%, т.е. на 2,3\%. Наибольшей (32\% и более в оба года) доля домохозяйств с двумя детьми среди всех домохозяйств с детьми была в республиках Бурятия, Адыгея, Алтай, Тыва, Чувашская, Татарстан, Башкортостан, Дагестан, Карачаево-Черкесская, Калмыкия, Кабардино-Балкарская, Северная Осетия, Ставропольском крае. Наименьшей (24\% и менее в 2002 или 2010 г.) доля таких домохозяйств была в Тульской, Ярославской, Магаданской, Ивановской, Московской, Владимирской, Мурманской, Смоленской, Сахалинской, Рязанской, Псковской, Нижегородской, Ленинградской, Воронежской, Орловской областях, Республике Ингушетия, Хабаровской крае, городах Москве и Санкт-Петербурге.

Доля таких домохозяйств сократилась, но в 23 регионах она возросла. При этом в 14 регионах она выросла более чем на 1\%: во Владимирской (на $2,2 \%$ ), Московской (на 4,4\%), Тульской (на 1,2\%), Ярославской (на 1,4\%), Калининградской (на 4,3\%), Мурманской (на 3,8\%), Магаданской (на 6,8\%), Сахалинской (на 4,1\%) областях, республиках Ингушетия (на 24,1\%), Алтай (на 2,3\%), Алтайском крае (на 1,7\%), Чукотском автономном округе (на 4,3\%), городах Москве (на 1,7\%), Санкт-Петербурге (на 1,1\%). Снижение доли таких домохозяйств было наибольшим в 10 регионах: Ульяновской (на $12,6 \%$ ), Белгородской (на 7,9\%), Брянской (на 6,8\%), Омской (на 6,5\%) облас- 
тях, республиках Татарстан (на 10,4\%), Мордовия (на 10,1\%), Башкортостан (на 10,0\%), Марий Эл (на 9,8\%), Чувашская (на 9,3\%), Калмыкия (на 7,0).

Снижение доли было меньше в ЦФО, СЗФО и ДФО - регионах, в которых уровень рождаемости активно рос, а в ПФО, который отставал от них по темпам увеличения рождаемости, снижение было больше.

Число членов домохозяйств с двумя детьми в среднем по стране сократилось, но в регионах с высокой рождаемостью или высоким уровнем жизни - республиках Дагестан, Ингушетия, Чеченская и г. Москве выросло на 8,7; 2,0; 3,4 и $1,8 \%$. В семи регионах сокращение составило менее $10 \%$ : в Московской области $(2,3 \%)$, республиках Карачаево-Черкесская (6,9\%), Северная Осетия $(9,7 \%)$, Алтай $(5,6 \%)$, Тыва (3,9\%), Саха (Якутия) $(9,1 \%)$, Чукотском автономном округе $(8,8 \%)$. Наибольшим снижение было в ЦФО, СЗФО, ПФО: в Брянской $(25,1 \%)$, Псковской $(25,7 \%)$, Тамбовской $(26,7 \%)$, Курской $(27,0 \%)$, Кировской $(27,5 \%)$, Курганской $(27,6 \%)$, Ульяновской $(33,7 \%)$ областях, республиках Коми $(25,4 \%)$, Марий Эл (26,3\%), Чувашская (26,3\%), Мордовия (29,6\%).

Снижение среднего размера домохозяйств с двумя детьми наблюдалось в основном в регионах с высокой рождаемостью: в Мурманской (на 0,8\%), Магаданской (на 0,1\%) областях, республиках Дагестан (на 0,3\%), Ингушетия (на 9,8\%), Чеченская (на 3,0\%), Алтайском (на 0,4\%), Камчатском (на 0,1\%) краях. Увеличение среднего размера домохозяйств на $2 \%$ и более было в регионах, в которых рождаемость повышалась: в Ленинградской $(2,8 \%)$, Астраханской $(2,3 \%)$, Пензенской $(2,2 \%)$, Калужской $(2,0 \%)$ областях, республиках Калмыкия (4,3\%), Карачаево-Черкесская $(4,2 \%)$, Марий Эл $(3,5 \%)$, Северная Осетия (3,2\%), Мордовия (2,5\%), Бурятия (2,3\%), Адыгея (2,3\%), Башкортостан $(2,2 \%)$, Чувашская $(2,1 \%)$, Чукотском автономном округе $(2,4 \%)$.

Модели конвергенции характеристик домохозяйств с двумя детьми

Таблий 2

\begin{tabular}{|c|c|c|c|c|c|}
\hline Модель 1 & Коэффициент & $\begin{array}{c}\text { Стандартная } \\
\text { ошибка }\end{array}$ & $\begin{array}{c}\text { P- } \\
\text { значение }\end{array}$ & $\begin{array}{c}\text { R- } \\
\text { квадрат }\end{array}$ & $\begin{array}{c}\text { Исправленный } \\
\text { R-квадрат }\end{array}$ \\
\hline const & $-0,02146$ & 0,01627 & 0,1912 & \multirow[t]{2}{*}{0,0002} & \multirow[t]{2}{*}{$-0,0126$} \\
\hline l v2002 & $-0,00019$ & 0,00149 & 0,8971 & & \\
\hline Модель 2 & Коэффициент & $\begin{array}{l}\text { Стандартная } \\
\text { ошибка }\end{array}$ & $\begin{array}{l}\text { Р- } \\
\text { значение }\end{array}$ & $\begin{array}{l}\text { R-ква- } \\
\text { драт }\end{array}$ & $\begin{array}{l}\text { Исправленный } \\
\mathrm{R} \text {-квадрат }\end{array}$ \\
\hline const & $-0,02936$ & 0,00992 & 0,0041 & \multirow[t]{2}{*}{0,0114} & \multirow[t]{2}{*}{$-0,0012$} \\
\hline 1_v2002 & 0,00346 & 0,00364 & 0,3451 & & \\
\hline Модель 3 & Коэффициент & $\begin{array}{l}\text { Стандартная } \\
\text { ошибка }\end{array}$ & $\begin{array}{l}\mathrm{P} \text { - } \\
\text { значение }\end{array}$ & $\begin{array}{l}\text { R-ква- } \\
\text { драт }\end{array}$ & $\begin{array}{l}\text { Исправленный } \\
\text { R-квадрат }\end{array}$ \\
\hline const & 0,07044 & 0,01247 & $2,54 \mathrm{e}-07$ & \multirow[t]{2}{*}{0,3039} & \multirow[t]{2}{*}{0,2950} \\
\hline $1 \mathrm{v} 2002$ & $-0,02180$ & 0,00374 & $1,16 \mathrm{e}-07$ & & \\
\hline Модель 4 & Коэффициент & $\begin{array}{l}\text { Стандартная } \\
\text { ошибка }\end{array}$ & $\begin{array}{l}\text { P- } \\
\text { значение }\end{array}$ & $\begin{array}{l}\text { R-ква- } \\
\text { драт }\end{array}$ & $\begin{array}{l}\text { Исправленный } \\
\mathrm{R} \text {-квадрат }\end{array}$ \\
\hline const & $-0,02808$ & 0,01725 & 0,1077 & \multirow[t]{2}{*}{0,0014} & \multirow[t]{2}{*}{$-0,0114$} \\
\hline 1 v2002 & 0,00046 & 0,00139 & 0,7436 & & \\
\hline Модель 5 & Коэффициент & $\begin{array}{l}\text { Стандартная } \\
\text { ошибка }\end{array}$ & $\begin{array}{l}\mathrm{P} \text { - } \\
\text { значение }\end{array}$ & $\begin{array}{l}\text { R-ква- } \\
\text { драт }\end{array}$ & $\begin{array}{l}\text { Исправленный } \\
\text { R-квадрат }\end{array}$ \\
\hline const & 0,02458 & 0,00423 & $1,28 \mathrm{e}-07$ & \multirow[t]{2}{*}{0,2831} & \multirow[t]{2}{*}{0,2739} \\
\hline 1 v2002 & $-0,01603$ & 0,00289 & $3,80 \mathrm{e}-07$ & & \\
\hline
\end{tabular}

Источник: расчеты автора на основе [17-18]. 
В табл. 2 представлены результаты эконометрического моделирования. В модели 1 изучается сближение по числу домохозяйств с двумя детьми, в модели 2 - по доле домохозяйств с двумя детьми среди всех домохозяйств, в модели 3 - по доле домохозяйств с двумя детьми во всех домохозяйствах с детьми, в модели 4 - по числу членов домохозяйств с двумя детьми, в модели 5 - по среднему размеру домохозяйств с двумя детьми.

Модели 1, 2 и 4 не значимы, a R-квадрат в них крайне мал, поэтому мы исключаем их из рассмотрения. Модель 3 значима на уровне $1 \%$, хотя Rквадрат в ней не очень большой. Тем не менее мы можем говорить о сближении регионов по доле домохозяйств с двумя детьми во всех домохозяйствах с детьми. Модель 5 тоже значима на уровне 1\%, но R-квадрат в ней немного ниже. Это свидетельствует о невысокой объяснительной силе модели, но мы можем говорить и о сближении регионов по среднему размеру домохозяйств с двумя детьми. Сближение вызвано замедлением прироста рождаемости на Юге России и тенденциями, направленными на нуклеаризацию общества в этих регионах, а также увеличением рождаемости в остальных регионах.

\section{Изменение числа домохозяйств с детьми до 18 лет с тремя и более детьми}

За межпереписной период число домохозяйств с тремя и более детьми сократилось с 1396 тыс. до 1250 тыс. (на 10,5\%), число членов в них - с 8542 тыс. чел. до 7671 тыс. чел. (на 10,2\%), а средний размер таких домохозяйств немного увеличился (на 0,02 чел., т.е. на 0,3\%).

Число домохозяйств с тремя и более детьми возросло только в четырех регионах: Московской области (на 27,7\%), Чеченской Республике (на 6,7\%), городах Москве (на 43\%) и Санкт-Петербурге (на 7,3\%). Еще в 21 регионе (в основном с высоким уровнем жизни или с высокой рождаемостью) сокращение составило менее $10 \%$. Больше всего таких регионов было в ЮФО, СКФО и ЦФО, меньше всего - в СЗФО и ДФО. Снижение наблюдалось почти во всех федеральных округах, но было наибольшим в Ульяновской (на 24,8\%), Амурской (на 25,4\%), Архангельской (на 26,9\%), Еврейской автономной (на $33,2 \%$ ) областях, республиках Ингушетия (на 24,6\%), Марий Эл (на 26,1\%), Кабардино-Балкарская (на 26,2\%), Коми (на 27,9\%), Чувашская (на 31,4\%), Забайкальском (на 24,3\%), Приморском (на 26,7\%), Хабаровском (на 27,0\%) краях.

Доля домохозяйств с тремя и более детьми среди всех домохозяйств сократилась с 3,4 до 3,1\%, т.е. на 0,3 процентных пункта (9,5\%). Наиболее высокой (10\% и более в 2002 г.) их доля была в регионах с традиционно большими семьями и высокой рождаемостью: республиках Северная Осетия, Саха (Якутия), Карачаево-Черкесская, Кабардино-Балкарская, Тыва, Дагестан, Чеченская, Ингушетия. В двух последних доля таких домохозяйств в 2002 г. составляла 42,1 и 54,2\%, а в 2010 г. - 35,3 и 38,8\%. Наименьшей (от 1 до 2\%) доля таких домохозяйств была в 22 регионах ЦФО (в том числе в Московской, Рязанской областях и г. Москве), СЗФО, ПФО и Сахалинской области, т.е. в регионах с низкой рождаемостью и маленькими семьями. 
Увеличение доли таких домохозяйств отмечалось в Московской (на $20,1 \%$ ), Рязанской (на 5,1\%) областях, Республике Адыгея (на $0,8 \%$ ), городах Москва (на 23,4\%), Санкт-Петербург (на 2,0\%). В 34 регионах снижение составило менее $10 \%$, что связано с увеличением рождаемости во многих регионах. Наибольшим снижение было как в регионах, в которых прирост рождаемости замедляется, так и в регионах, в которых уровень рождаемости не восстановился до значений 1980-х гг.: Еврейской автономной области $(28,2 \%)$, республиках Марий Эл $(22,4 \%)$, Кабардино-Балкарская $(24,2 \%)$, Дагестан $(27,7 \%)$, Ингушетия $(28,5 \%)$, Чувашская $(28,7 \%)$, Забайкальском $(22,0 \%)$, Хабаровском $(22,5 \%)$, Приморском $(23,1 \%)$ краях.

Доля домохозяйств с тремя и более детьми среди всех домохозяйств с детьми возросла с 6,6 до 7,0\%, т.е. на 0,4 процентных пункта $(6,4 \%)$. Наиболее высокой ( $10 \%$ и более в 2002 или 2010 г.) доля таких домохозяйств была в регионах с высокой рождаемостью: республиках Адыгея, Бурятия, Алтай, Калмыкия, Саха (Якутия), Карачаево-Черкесская, Северная Осетия, Кабардино-Балкарская, Тыва, Дагестан, Чеченская, Ингушетия, Забайкальском крае, Чукотском автономном округе. В Чеченской Республике и Республике Ингушетия доля домохозяйств с тремя и более детьми среди всех домохозяйств с детьми в 2002 г. была 51,4 и $65,0 \%$, а в 2020 г. $-46,8$ и $53,8 \%$. Наименьшей (2-3\% в 2002 или 2010 г.) доля таких домохозяйств была в Мурманской, Московской, Ярославской, Ивановской, Нижегородской, Пензенской, Владимирской, Тульской, Самарской, Ленинградской, Смоленской, Рязанской областях, Республике Мордовия, городах Москве и Санкт-Петербурге - в регионах с сильным снижением рождаемости и (или) ее низким уровнем.

Наибольшим ( $10 \%$ и более) увеличение доли домохозяйств с тремя и более детьми среди всех домохозяйств с детьми было преимущественно в регионах с низкой рождаемостью и малым числом многодетных семей: в Московской $(38,5 \%)$, Рязанской $(26,4 \%)$, Пензенской $(19,2 \%)$, Калужской $(18,3 \%)$, Тульской $(16,0 \%)$, Мурманской $(14,3 \%)$, Липецкой $(13,7 \%)$, Свердловской $(13,6 \%)$, Владимирской $(13,2 \%)$, Кемеровской $(13,2 \%)$, Ярославской $(12,1 \%)$, Ленинградской $(11,9 \%)$, Магаданской $(10,7 \%)$, Тверской $(10,2 \%)$ областях, республиках Мордовия (17,7\%), Адыгея (15,1\%), городах Москве (43,6\%), Санкт-Петербурге $(24,9 \%)$. Наибольшее снижение доли таких домохозяйств $(10 \%$ и более) было зафиксировано в регионах с высокой рождаемостью: в Еврейской автономной области (16,2\%), Республиках Саха (Якутия) $(11,8 \%)$, Чувашская (13,9\%), Кабардино-Балкарская (14,3\%), Ингушетия $(17,2 \%)$, Дагестан $(19,7 \%)$, Забайкальском крае $(12,3 \%)$.

Число членов домохозяйств с тремя и более детьми возросло только в Московской (на 29,8\%), Рязанской (на 2,3\%) областях, республиках Адыгея (на 1,9\%), Карачаево-Черкесская (на 4,6\%), Чеченская (на 2,7\%), городах Москве (на 37,8\%) и Санкт-Петербурге (на 7,7\%). В 24 регионах снижение составило менее $10 \%$. Снижение числа членов таких домохозяйств было наибольшим в Амурской $(24,1 \%)$, Архангельской $(26,8 \%)$, Еврейской автономной $(31,4 \%)$ областях, республиках Кабардино-Балкарская $(24,9 \%)$, Коми $(27,5 \%)$, Чувашская $(28,7 \%)$, Ингушетия $(29,9 \%)$, Хабаровском $(26,1 \%)$, Приморском $(26,6 \%)$ краях. Изменения связаны как с миграцией, так и с рождаемостью. 
Средний размер домохозяйств с тремя и более детьми сократился только в 11 регионах: Мурманской (на 2,5\%), Кировской (менее чем на 0,1\%), Свердловской (менее чем на $0,1 \%$ ), Омской (на $0,6 \%$ ) областях, республиках Дагестан (на 3,2\%), Ингушетия (на 7,1\%), Чеченская (на 3,7\%), Тыва (на $0,6 \%$ ), Ставропольском (на 2,1\%), Алтайском (на 5,0\%) краях, г. Москве (на $3,6 \%)$. Увеличение было наибольшим (более $4 \%$ ) в Орловской $(4,3 \%)$, Ленинградской $(5,5 \%)$, Пензенской $(4,6 \%)$ областях, республиках КарачаевоЧеркесская (6,1\%), Марий Эл $(5,7 \%)$, Чувашская $(4,0 \%)$. Это связано с ростом рождаемости и взрослением детей, родившихся в 1980 -е гг.

В табл. 3 представлены результаты эконометрического моделирования. В модели 1 изучается сближение по числу домохозяйств с тремя и более детьми, в модели 2 - по доле домохозяйств с тремя и более детьми среди всех домохозяйств, в модели 3 - по доле домохозяйств с тремя и более детьми во всех домохозяйствах с детьми, в модели 4 - по числу членов домохозяйств с тремя и более детьми, в модели 5 - по среднему размеру домохозяйств с тремя и более детьми.

Таблица 3

Модели конвергенции характеристик домохозяйств с тремя детьми

\begin{tabular}{|c|c|c|c|c|c|}
\hline Модель 1 & Коэффициент & $\begin{array}{l}\text { Стандартная } \\
\text { ошибка }\end{array}$ & $\begin{array}{l}\text { P- } \\
\text { значение }\end{array}$ & $\begin{array}{l}\text { R- } \\
\text { квадрат }\end{array}$ & $\begin{array}{l}\text { Исправленный } \\
\text { R-квадрат }\end{array}$ \\
\hline const & $-0,05140$ & 0,01613 & 0,0021 & \multirow[t]{2}{*}{0,0558} & \multirow[t]{2}{*}{0,0437} \\
\hline 1_v2002 & 0,00368 & 0,00171 & 0,0348 & & \\
\hline Модель 2 & Коэффициент & $\begin{array}{l}\text { Стандартная } \\
\text { ошибка }\end{array}$ & $\begin{array}{l}\mathrm{P} \text { - } \\
\text { значение }\end{array}$ & $\begin{array}{l}\text { R- } \\
\text { квадрат }\end{array}$ & $\begin{array}{l}\text { Исправленный } \\
\text { R-квадрат }\end{array}$ \\
\hline const & $-0,00506$ & 0,00215 & 0,0208 & \multirow[t]{2}{*}{0,2073} & \multirow[t]{2}{*}{0,1971} \\
\hline 1_v2002 & $-0,00690$ & 0,00153 & $2,21 \mathrm{e}-05$ & & \\
\hline Модель 3 & Коэффициент & $\begin{array}{l}\text { Стандартная } \\
\text { ошибка }\end{array}$ & $\begin{array}{l}\mathrm{P} \text { - } \\
\text { значение }\end{array}$ & $\begin{array}{l}\text { R- } \\
\text { квадрат }\end{array}$ & $\begin{array}{l}\text { Исправленный } \\
\text { R-квадрат }\end{array}$ \\
\hline const & 0,02544 & 0,00313 & $5,08 \mathrm{e}-012$ & \multirow[t]{2}{*}{0,3939} & \multirow[t]{2}{*}{0,3861} \\
\hline 1_v2002 & $-0,01158$ & 0,00163 & $4,67 \mathrm{e}-010$ & & \\
\hline Модель 4 & Коэффициент & $\begin{array}{l}\text { Стандартная } \\
\text { ошибка }\end{array}$ & $\begin{array}{l}\mathrm{P} \text { - } \\
\text { значение }\end{array}$ & $\begin{array}{l}\text { R- } \\
\text { квадрат }\end{array}$ & $\begin{array}{l}\text { Исправленный } \\
\text { R-квадрат }\end{array}$ \\
\hline const & $-0,04491$ & 0,01875 & 0,0190 & \multirow[t]{2}{*}{0,0312} & \multirow[t]{2}{*}{0,0188} \\
\hline 1_v2002 & 0,00266 & 0,00168 & 0,1169 & & \\
\hline Модель 5 & Коэффициент & $\begin{array}{l}\text { Стандартная } \\
\text { ошибка }\end{array}$ & $\begin{array}{l}\mathrm{P} \text { - } \\
\text { значение }\end{array}$ & $\begin{array}{l}\text { R- } \\
\text { квадрат }\end{array}$ & $\begin{array}{l}\text { Исправленный } \\
\text { R-квадрат }\end{array}$ \\
\hline const & 0,03091 & 0,00722291 & $5,27 \mathrm{e}-05$ & \multirow[t]{2}{*}{0,1743} & \multirow[t]{2}{*}{0,1637} \\
\hline 1_v2002 & $-0,01651$ & 0,00406852 & 0,0001 & & \\
\hline
\end{tabular}

Источник: расчеты автора на основе [17-18].

Модель 4 не значима даже на уровне $10 \%$, a R-квадрат в ней очень маленький, поэтому мы ее не рассматриваем. Модель 1 значима на уровне 5\%, но R-квадрат в ней тоже очень мал. Это свидетельствует о невключении в две первые модели каких-то важных переменных. Модели 2 и 5 значимы на уровне $1 \%$, R-квадрат в них относительно невелик, но мы можем говорить о сближении регионов по доле домохозяйств с тремя и более детьми во всех домохозяйствах и по их среднему размеру. В модели 3 R-квадрат самый высокий и также наблюдается сближение регионов. 


\section{Выводы и рекомендации по совершенствованию государственной политики}

Проведенное исследование показало, что за межпереписной период число всех типов домохозяйств с детьми до 18 лет сократилось. Сократилась и их доля среди всех домохозяйств, а также число членов в них, что является негативным результатом, так как свидетельствует о снижении числа семей с детьми. В недалекой перспективе это может привести к увеличению нагрузки на экономику России, поскольку связи между членами общества ослабеют при увеличении числа пожилых и снижении числа молодых людей. Увеличение доли домохозяйств с тремя и более детьми является положительным фактом, но это увеличение незначительно на фоне общего снижения. Кроме того, число таких домохозяйств тоже сократилось.

Можно выделить несколько причин такой динамики: резкое и сильное снижение рождаемости в 1990-е гг. после периода высокой рождаемости в 1980-е гг., взросление многочисленных поколений детей, рожденных в 1980-е гг., при постарении возрастной модели рождаемости, социальная и экономическая нестабильность, а также снижение потребности в детях.

Суммарный коэффициент рождаемости в 1980-е гг. благодаря мерам демографической политики смог превысить уровень простого воспроизводства $(2,1)$ [19. С. 95]. События 1990-х гг. снизили его до крайне низких значений. Минимум $(1,157)$ был зафиксирован в 1999 г. [19. С. 95]. Начавшийся после этого рост рождаемости был значительным, но не достиг уровня 1980-х годов, что привело к снижению числа домохозяйств с детьми до 18 лет.

Социально-экономические трансформации 1990-2000-х гг. привели и к тайминговым сдвигам в сфере рождаемости, что также явилось причиной снижения числа домохозяйств с детьми.

Наконец, значительную роль сыграло снижение потребности в детях. Еще в 1981 г. А.Я. Кваша писал, что «необходимо учитывать прежде всего роль и место детей в системе жизненных ценностей семей той группы населения, к которым принадлежат супруги либо на которую они ориентируются. Это достаточно сильный... фактор. По сути дела, речь идет, хотя это и не очень точно, о том, сколько «модно», «прилично» иметь детей в семье» [20. С. 155]. Это означает, что «роль детей все более и более сводится к престижному их значению, а значит, в какой-то мере к заменяемому другими элементами компоненту обязательного набора жизненных ценностей» [20. С. 114].

Согласно обследованиям, в современной России существующая социальная норма детности предполагает, что в семье должно быть не более двух детей, но один необходим для самореализации женщины [21]. Это можно связать со снижением потребности в детях. По мнению В.Н. Архангельского, в современном обществе спектр мотивов откладывания рождений детей расширяется [22. С. 45]. Это свидетельствует о том, что ценность детей второй и более высоких очередностей рождения зависит от установок женщин и поведения окружающих [20. С. 166; 23. С. 230-231, 235-236; 24].

Регионы, в которых снижение числа домохозяйств было минимальным, это регионы с высокой рождаемостью, расположенные в СКФО и ЮФО, а также некоторые регионы СФО и ДФО. Также к ним относятся регионы с 
высоким уровнем жизни в целом по стране или среди соседей - Московская, Тюменская, Калининградская области, Краснодарский, Ставропольский край, города Москва, Санкт-Петербург. Снижение числа домохозяйств с детьми было наибольшим в регионах ЦФО, СЗФО, ПФО, Курганской области.

Снижение числа домохозяйств с детьми было максимальным в отношении домохозяйств с двумя детьми, а в отношении домохозяйств с тремя и более детьми снижение было наименьшим. К сожалению, мы не знаем, что является причиной увеличения рождаемости в настоящее время - тайминговый сдвиг или что-то другое, поэтому дать оценку произошедшим изменениям сложно. Тем не менее снижение числа домохозяйств с детьми является негативным результатом и означает необходимость значительных усилий для повышения престижа семей с детьми.

Среди мер, направленных на повышение значимости семей с детьми, особенно следует выделить две. Из данных переписей следует, что демографические потери были меньше в регионах с высоким уровнем жизни. Следовательно, первой мерой является повышение уровня жизни таких семей. Второй мерой является развитие «детской» инфраструктуры. Это необходимо, так как она снижает затраты родителей на уход за детьми и их воспитание, повышая при этом их человеческий капитал.

Процесс реализации государственной политики должен подкрепляться информационными мерами. Для этого необходимы переписи, без которых важная информация недоступна. Более частной, но не менее важной мерой является учет органами статистики очередности рождения. Такие данные необходимы каждый год, а не только в годы проведения переписей, поэтому публикации Росстата, посвященные рождаемости (например, «Демографический ежегодник» и прочие ежегодники, а также статистические базы Росстата EМИСС (https://www.fedstat.ru/) и ЦБСД (http://cbsd.gks.ru/)), должны быть дополнены соответствующими сведениями (хотя бы в электронном формате).

\section{Лuтература}

1. Курагина Г.С. Особенности социализации детей из неполных семей // Академия профессионального образования. 2015. № 7 (49). С. 47-52.

2. Мошкович О.С., Гольменко А.Д. Особенности психологической готовности к браку девушек из неполных семей // От истоков к современности. 130 лет организации психологического общества при Московском университете: сб. материалов юбилейной конф.: в 5 т. М.: КогитоЦентр, 2015. Т. 3. С. 207-229.

3. Слинькова Т.В. Гендерные стереотипы подростков, воспитывающихся в полных и неполных семьях // Гуманитарное знание: сб. науч. ст. Сер. «Научные горизонты» / под общ. ред. В.Г. Егоркина. Вып. 13. СПб.: Центр научно-информационных технологий «Астерион», 2009. C. $90-98$.

4. Чурилова Е.В. Состав и благосостояние неполных семей в России // Социологические исследования. 2015. № 3 (371). С. 78-81.

5. Черешова С.B. Социально-экономические факторы развития сектора домохозяйств, имеющих трех и более детей // Социально-экономические и пространственно-временные особенности развития демографических процессов в регионах России: сб. материалов VI Уральского демографического форума с международным участием «Экономико-демографическое поведение домохозяйств в условиях перехода на инновационный тип развития». Т. 2. Екатеринбург: Институт экономики Уральского отд-ния РАН, 2015. С. 175-180. 
6. Акинин П.В., Сивоплясова С.Ю. Социально-демографический портрет многодетной семьи в России: проблемы, поиски, решения // Национальные интересы: приоритеты и безопасность. 2009. № 23. С. 45-49.

7. Баранцева Н.А. Особенности эволюции семьи в Хакасии в конце 1980-х - 2010-е гг. // Вестн. Том. гос. ун-та. 2016. № 404. С. 32-41.

8. Филимонова М.A. Особенности развития сельских домохозяйств в Саратовском регионе // Изв. Сарат. ун-та. Новая серия. Серия «Социология. Политология». 2008. Т.8, № 2. С. 6367.

9. Абанокова К.Р. Изменения в структуре российских домохозяйств в 1994-2013 гг. (статистический анализ) // Демографическое обозрение. 2015. Т. 2, № 1. С. 125-147.

10.Прокофьева Л.М. Семейная структура населения России: тенденции последнего десятилетия // Народонаселение. 2013. № 2 (60). С. 72-84.

11. Abanokova K.M., Lokshin M. Changes in household composition as a shock-mitigating strategy // Economics in transition. 2015. Vol. 23, no 2. P. 371-388.

12. Кучмаева O.В. Последствия трансформации института семьи // Экономика, статистика и информатика // Вестн. УМО. 2010. № 1. С. 99-104.

13.Ларина Т.Н. Социально-экономическое положение домохозяйств в РФ (по данным переписи населения 2002 г.) // Изв. Оренбург. гос. аграрного ун-та. 2004. Т. 1, №. 1-1. С. 68-70.

14. Збарская И.А. Демографическая, национальная и социальная структура общества: итоги Всероссийской переписи населения 2002 года // Социология власти. 2004. № 5. С. 105-123.

15.Лобанова Н.В. Особенности семейного состава населения Волгоградской области (по результатам Всероссийской переписи населения 2010 г.) // Грани познания. 2013. № 3(23). C. $70-73$.

16. Sala-i-Martin X.X. The Classical Approach to Convergence Analysis // The Economic Journal. 1996. Vol. 106, №. 437. Р. 1019-1036.

17.Итоги Всероссийской переписи населения 2002 г.: в 14 т. Т. 6: Число и состав домохозяйств. М.: ИИЦ «Статистика России», 2005. 456 с.

18.Итоги Всероссийской переписи населения 2010 г.: в 11 т. Т. 6: Число и состав домохозяйств. М.: ИИЦ «Статистика России», 2013. 543 с. 397 c.

19.Демографический ежегодник России. 2002: стат. сб. М.: Госкомстат России, 2002.

20. Кваша А.Я. Демографическая политика в СССР. М.: Финансы и статистика, 1981. 200 с.

21.Синявская О.В., Тындик А.О., Головляницина Е.Б. В каких семьях рождаются дети? Факторы репродуктивного поведения в России // Семья в центре социально-демографической политики? Сборник аналитических статей / отв. ред. О.В. Синявская. М.: НИСП, 2009. С. 19-46.

22. Архангельский В.Н. Факторы рождаемости. М.: ТЕИС, 2006. 399 с.

23.Головляницина Е.Б. Роль социально-психологических факторов в репродуктивных намерениях // Родители и дети, мужчины и женщины в семье и обществе. М.: НИСП, 2007. C. $217-250$.

24.Безрукова О.Н. Демографическая политика государства в области рождаемости: пути преодоления кризиса // Вестн. С.-Петербург. ун-а. Серия 12. Психология. Социология. Педагогика. 2008. № 3. С. 196-211.

Sinitsa Arseniy L. Lomonosov Moscow State University (Moscow, Russia). E-mail: sinitsa@econ.msu.ru

\section{VARIOUS HOUSEHOLDS WITH CHILDREN ACCORDING TO THE 2002 AND 2010 POPULATION CENSUSES}

Keywords: household, children, regions, Russia, convergence, differentiation, demographic development, population census, social policy, family.

On the basis of census data of 2002 and 2010 the paper examines change in the number of households with one, two, three or more children less than 18 years in Russia's regions. The analysis showed better situation in regions with a high living standard and in regions with a high birth rate, and a worse one in the northern regions and in the Central part of Russia. The grounds for the differences are cultural and economic features, as well as demographic development in 1980-1990. 


\section{References}

1. Kuragina G.S., Osobennosti sotsializatsii detey iz nepolnykh semey // Academy of Professional Education. 2015. № 7 (49), pp. 47-52.

2. Moshkovich O.S., Golmenko A.D., Osobennosti psikhologicheskoy gotovnosti k braku devushek iz nepolnykh semey // Ot istokov k sovremennosti. 130 let organizatsii psikhologicheskogo obshchestva pri Moskovskom universitete: sbornik materialov yubileynoy konferentsii v 5 tomakh. Text 3. Moscow: Publishing house Kogito-Tsentr, 2015, pp. 207-229.

3. Slinkova T.V. Gendernyye stereotipy podrostkov, vospityvayushchikhsya v polnykh i nepolnykh semyakh // Gumanitarnoye znaniye. Sbornik nauchnykh statey. Ser. "Nauchnyye gorizonty" edited by V.G. Yegorkina. Vyp. 13. St. Petersburg: Center for Scientific and Information Technologies "Asterion"2009, pp. 90-98.

4. Churilova Ye.V., Sostav i blagosostoyaniye nepolnykh semey v Rossii // Sociological research. 2015. № 3 (371), pp. 78-81.

5. Chereshova S.V., Sotsialno-ekonomicheskiye faktory razvitiya sektora domokhozyaystv, imeyushchikh trekh i boleye detey // Sotsialno-ekonomicheskiye i prostranstvenno-vremennyye osobennosti razvitiya demograficheskikh protsessov v regionakh Rossii. Sbornik materialov VI Ural'skogo demograficheskogo foruma s mezhdunarodnym uchastiyem: Ekonomiko-demograficheskoye povedeniye domokhozyaystv $\mathrm{v}$ usloviyakh perekhoda na innovatsionnyy tip razvitiya. $\mathrm{T} 2$. Ekaterinburg: Institute of Economics of the Ural Branch of the Russian Academy of Sciences, 2015, pp. 175-180.

6. Akinin P.V., Sivoplyasova S.YU., Sotsialno-demograficheskiy portret mnogodetnoy semi v Rossii: problemy, poiski, resheniya // Natsionalnyye interesy: prioritety i bezopasnost'. 2009. № 23, pp. 45-49.

7. Barantseva N.A., Osobennosti evolyutsii semi v Khakassii v kontse $1980-2010$. // Bulletin of Tomsk State University. 2016. № 404, pp. 32-41.

8. Filimonova M.A., Osobennosti razvitiya selskikh domokhozyaystv v Saratovskom regione // Bulletin of Saratov University. New episode. Series. Sociology. Political science.2008. Text 8. № 2, pp. 63-67.

9. Abanokova K.R., Izmeneniya v strukture rossiyskikh domokhozyaystv v 1994-2013. (Statistical analysis) // Demograficheskoye obozreniye. 2015. Vol. 2. № 1, pp. 125-147.

10. Prokofyeva L.M., Semeynaya struktura naseleniya Rossii: tendentsii poslednego desyatiletiya // Narodonaseleniye. 2013. № 2 (60), pp. 72-84.

11. Abanokova K.M., Lokshin M., Changes in household composition as a shock-mitigating strategy // Economics in transition. 2015. Volume 23. no 2, pp. 371-388.

12. Kuchmayeva O.V., Posledstviya transformatsii instituta semi // Ekonomika, statistika i informatika. Bulletin of UMO. 2010. № 1, pp. 99-104.

13. Larina T.N., Sotsialno-ekonomicheskoye polozheniye domokhozyaystv v RF (according to the 2002 census) // Proceedings of the Orenburg State Agrarian University.2004. Text 1. №. 1-1, pp. 68-70.

14. Zbarskaya I.A., Demograficheskaya, natsionalnaya i sotsialnaya struktura obshchestva: the results of the All-Russia population census of 2002 // Sotsiologiya vlasti. 2004. № 5, pp. 105-123.

15. Lobanova N.V., Osobennosti semeynogo sostava naseleniya Volgogradskoy oblasti (the results of the All-Russia population census of 2010.) // Grani poznaniya. 2013. № 3(23), pp. 70-73.

16. Sala-i-Martin X. X., The Classical Approach to Convergence Analysis // The Economic Journal. 1996. Volume 106. №. 437, pp. 1019-1036.

17. The results of the All-Russia population census of 2002 in 14 volumes. Text 6 . Chislo i sostav domokhozyaystv. Moscow: Information and Analysis Center "Statistics of Russia",2005, p. 456.

18. Results of the All-Russia Population Census of 2010 in 11 volumes. Text 6. Chislo i sostav domokhozyaystv. Moscow: Information and Analysis Center "Statistics of Russia", 2013. p. 543.

19. Demographic Yearbook of Russia. 2002: Stat. sb. Moscow: Goskomstat Rossii. 2002. pp. 397

20. Kvasha A.YA., Demograficheskaya politika v SSSR. Moscow: Finansy i statistika, 1981, p. 200 .

21. Sinyavskaya O.V., Tyndik A.O., Golovlyanitsina Ye.B., V kakikh semyakh rozhdayutsya deti? Faktory reproduktivnogo povedeniya v Rossii. // Semya v tsentre sotsial'no-demograficheskoy politiki? Sbornik analiticheskikh statey / Edited by O.V. Sinyavskaya. Moscow: Independent Institute of Social Policy, 2009, pp. 19-46.

22. Arkhangelskiy V.N., Faktory rozhdayemosti. Moscow: Publishing house "TEIS", 2006, p. 399 . 
23. Golovlyanitsina Ye.B., Rol' sotsialno-psikhologicheskikh faktorov $\mathrm{v}$ reproduktivnykh namereniyakh // Roditeli i deti, muzhchiny i zhenshchiny v semye i obshchestve. Moscow: Independent Institute of Social Policy, 2007, pp. 217-250.

24. Bezrukova O.N., Demograficheskaya politika gosudarstva v oblasti rozhdayemosti: puti preodoleniya krizisa // Bulletin of St. Petersburg University. Series 12. Psychology. Sociology. Pedagogy. 2008. № 3, pp. 196-211.

Sinitsa A.L. Chislo domohozjajstv s det'mi razlichnogo tipa po dannym perepisej naselenija 2002 i 2010 godov [Various households with children according to the 2002 and 2010 population censuses]. Vestnik Tomskogo gosudarstvennogo universiteta. Ekonomika - Tomsk State University Journal of Economics, 2017, no 38, pp. 106-121. 